\title{
The Heart as a Compass: Preaching Self-worth and Success to Single Young Women in a Nigerian Pentecostal Church
}

\author{
Juliet Gilbert \\ Department of African Studies \& Anthropology, University of Birmingham, \\ Birmingham, U K \\ j.gilbert.2@bham.ac.uk
}

\begin{abstract}
The quiet city of Calabar in southeastern Nigeria is famed for its burgeoning church scene offering various spiritual services. In this religious marketplace, The Brook Church stands out due to its beautiful building, well-dressed congregation, clever branding, and its 'unique' preaching. Focusing on young women's engagement with The Brook Church, this article builds on recent analyses seeking to understand the attraction of Pentecostalism for this often marginalised and disenfranchised social group. Examining The Brook Church's life-affirming doctrine of Zoe, in which individual aspirations are realised through careful and timely management of the religious self, the article explores how religious action and rhetoric mould new subjectivities aimed for success. Illustrating how Pentecostal practice gives young women a newfound sense of self-worth and confidence, the article's emphasis on the individual project suggests we should broaden debates that solely equate young women's engagement with Pentecostalism with sexuality and marriage opportunities.
\end{abstract}

\section{Keywords}

Nigeria - Pentecostalism - young women - aspirations - religious practice self-management 


\section{Introduction}

'Make a date with me by $6 \mathrm{pm}$ tmrw in Church for Sisters' Talk \& get the understanding you need to transition. Pastor Ose.' In tune with Pentecostalism's propensity for clever marketing, this text message was the final reminder for single young women to attend The Brook Church's marriage preparation programme. Held on a Sunday evening, the biannual programme is put on in conjunction with an equivalent programme for single men. With the exceptions of Pastor Ose and the largely male worship band, Sisters' Talk temporarily transforms the church into a predominantly female space. It is a more intimate environment than the usual service, and young women attend from all over the city by themselves and are often invited by church members wanting others to benefit from Pastor Ose's counsel. With CDs of Pastor Ose's message available on sale afterwards for further digest and dissemination, the programme is a bite-sized nugget of how The Brook Church's doctrine should play out in the lives of single young women in Calabar, southeastern Nigeria.

At precisely 6:00 p.m. the programme opened with a biblical reading reminding the female congregants to listen to God's Word. Next came rapturous praise and worship to invite the Spirit into the meeting. With spirits lifted and a sense of focus established in the church, Pastor Ose came to the front to present the programme's topic: 'True Womanhood'. The sixty or so young women, the vast majority of whom were in their twenties, sat quietly. Dressed in skinny jeans, fitted tops, and embellished leather sandals, and with long braids or 'weaveons', they all ascribed to a fashionable urban aesthetic. As with the usual service, they followed the biblical passages in their Bibles, on their BlackBerries, or from the projection on the wall, and studiously took notes in jotter pads, eager to not miss points that they could revise later in their own private prayer-time.

Starting with Bible passages from Genesis, Pastor Ose defined womanhood as something to be celebrated:made in God's image and created to complement man, a woman needs to have a good self-definition in order to demonstrate God's glory and vision. According to The Brook Church, this self-definition depends on one's heart. Considered the source of woman's spiritual strength, the heart renders her prayers powerful, yet it is also easily corruptible by enemies ready to cause confusion and misfortune. To maintain spiritual strength, Pastor Ose encourages young women to steep their hearts in the Word of God, and then use their hearts as a guiding compass in life. With the needle directing her to her personal ambitions, a woman can realise her self-worth and can also question what kind of value projects and people add to her journey. While Sisters' Talk was aimed at singles preparing for marriage, the focus was very much on the individual self. Although marriage is undoubtedly one important 
goal, it is not the only goal in God's vision for young women. Almost akin to a life-coaching meeting, Pastor Ose encouraged the single women to discard the negative and focus on the positive that they should see in themselves.

Indeed, this message was preached once again in the question time that followed Pastor Ose's sermon. The young women asked how to overcome dreams signalling misfortune, how to ask for forgiveness after already having consummated a relationship, and whether continuing a relationship with a Catholic could ever lead to a productive marriage. Finally, a question was raised concerning destiny: did marriage stop a woman from finding her God-given purpose in life? Pastor Ose was adamant that marriage did not stop God's vision but that a woman must know herself, find her purpose first, and marry according to it. Giving an example, Pastor told the congregation about a 'very wonderful sister' in the church who was really going places and had plans to marry a top lawyer. The young woman had told the pastor how fantastic the man was, although she admitted that there was one problem: he was not impressed by her dreams of having a successful career. The man wanted his wife to be in the kitchen, not climbing the career ladder. Pastor pointed out that although the man appeared to be a perfect suitor, in fact he was not right for the woman because he did not support her 'God-given purpose'.

\section{Preparing Pentecostal Subjectivities}

Using the Sisters' Talk programme as a point of departure, I examine how The Brook Church gives young women a newfound sense of self-confidence and belief in personal success as singles. In doing so, the discussion builds on the rapidly expanding body of literature that documents the various guises of Pentecostal Christianity across the African continent (e.g., Maxwell 1998; Meyer 1998; Marshall 2009; Cole 2010; Pype 2012). Surprisingly, against this plethora of Pentecostal studies, analyses of young women's involvement with the movement in Africa remain nascent. For instance, literature on Nigerian Pentecostalism has paid attention to how the movement started as a religion for marginalised youth on student campuses in the 1970s (Ojo 1988; Marshall 1991). However, far less attention has been paid to young women's particular involvement with Pentecostalism and the various ways in which, through the movement's emphasis on spiritual power, this group seek emancipation from the cleavages of gender and generation that characterise their lived experiences in Nigeria.

Introducing a special issue of Journal of Religion in Africa, Bochow and van Dijk (2012) present one analytical framework to help us understand young 
women's attraction to Pentecostalism across the African continent. Drawing on Hetherington's (1997) Foucauldian concept of heterotopia, the authors argue that the power of the Pentecostal movement lies in its ability to create an alternative space for its young female congregants, a space that removes them from the confining power relations and conservative views of normal life. The ways in which Pentecostalism provides advice on health care, the body, sexuality, and relationships carve out a social arena for young women in which alternative social relations challenge the status quo. For instance, writing in the same issue, Frahm-Arp (2012) argues that Pentecostalism has gained popularity in South Africa by allowing women to negotiate single life with the Christian calling of marriage. Contrary to traditional South African social expectations, Pentecostalism creates a social environment in which successful careers are not detrimental to either marriage prospects or spirituality. Further acknowledging how the movement renders bodies as sites of restraint, Pearce (2012) argues that Pentecostal churches in southwest Nigeria set themselves apart from others by offering 'emotional training'. Creating new ideals for young women to follow by regulating emotions, Charismatic churches play on fear and shame just as much as love and desire.

Such analyses highlighting how Pentecostalism attracts upwardly mobile women, not least through evolving relational ethics, identities, and gender roles (Bochow and van Dijk 2012), of course resonate with The Brook Church's emphasis on individual self-worth before marriage. Yet the focus on heterotopia or alternative social spaces becomes problematic by negating a real understanding of who these young women actually are, the social circles on which they rely, and, importantly, who they want to become through worshipping at Pentecostal churches. For instance, as a 'city of church industry' (Hackett 1989, 1), Calabar offers a thriving spiritual marketplace: the standardised doctrines of what are known locally as 'orthodox' churches (including the missionary Presbyterian, Catholic, Anglican, Qua Iboe churches, and AICs such as the Brotherhood of the Cross \& Star) compete against the cacophonous spiritual services of fellowships, ministries, clandestine healing homes, and, of course, the city's ever-growing and ever-diverse Pentecostal movement (Offiong 2003). Calabar's residents, including young women, take advantage of this spiritual marketplace by visiting a variety of ministries catering to different spiritual concerns, from fighting ancestral curses and witchcraft, to succeeding in academics, business, and love. Such worship practices are not always conducted openly, but are integral to an individual project of maintaining spiritual strength. In view of the number of different ministries, and the difficulty of reifying people's churchgoing practices, we may ask how far the alternative social realities Pentecostalism projects do go beyond the church. 
This question is especially pertinent to Calabar's single young women who seek spiritual fulfilment in Pentecostal churches. It was noticeable that many of the young women at the Sisters' Talk programme were not regular members of The Brook Church. In addition to young women's practice of picking and choosing programmes to answer their current spiritual problems, regular attendance at their church of choice is sometimes too costly due to high taxi fares. Young women will worship at a church near their house and venture further across the city only for particular programmes. Moreover, many young women, still under their father's roof, are only able to attend their church of choice when the services do not clash with their obligation to attend their family church, whether 'orthodox' or other Pentecostal ministries. While many young women I knew felt spiritually uplifted by Pentecostal preaching, it was not what they always heard at church each week or to what their immediate social circles, such as their family, subscribed. Hence it is questionable how neat the social spaces Bochow and van Dijk (2012) discuss actually are, or whether these alternative spaces remain distant utopias.

Rather, I argue that we learn much about young women's attraction to Pentecostalism by focusing on the individual and the making of the Pentecostal person. In view of the movement's central tenet of spiritual rebirth, ideas of personhood have been central to Pentecostal literature. For instance, Robbins' (2004) analysis of the Urapmin of Papua New Guinea illustrates the cultural rupture caused by conversion to Charismatic Christianity, in which spiritual rebirth reconfigures morality and selfhood in a way that the Urapmin actually become sinners as they break from cultural norms. Focusing on Africa, the anthropology of Christianity has begun to examine how Christian practices dovetail with emic conceptions of personhood. Pype (2011) and Daswani (2011) illustrate how worshippers must not only manage themselves but also relationships and obligations to others in religious practice. ${ }^{1}$ Crucially, this development of Christian personhood through interactions with God and other people is not a linear trajectory but a personal growth fraught with negotiations (Coleman 2011). Hence a focus on the growth of the individual person does not negate an understanding of social interactions; rather, I argue the need to focus on how Pentecostalism allows young women to view themselves differently, enabling them to navigate existing social spheres more successfully.

It is common for young women in Calabar to describe their spiritual life as a passage from Christian infancy to Christian adulthood, with spiritual maturation contingent on their ability to know God through effective religious practice. By studying the Bible and practising how to pray in tongues and carry out fasts, young women mature, receiving more rights and responsibilities as Christians. Hence people become religious subjects through the acts of worship 
they choose to carry out (cf. Mahmood 2005, 2009). Writing about Nigerian Pentecostalism, Marshall (2009) employs a Foucauldian framework of subjectification to argue that worshippers adopt and internalise Pentecostal practices, which, shaping the individual, become conceptualised as Pentecostal techniques of the self. As they change their religious convictions, their appearance, their actions and modes of expression to create a new political space for themselves, Nigerian Pentecostals challenge the 'epistemological, normative and ontological insecurity of life in urban postcolonial Nigeria' (Marshall 2009, 2; cf. Adogame 2010; Obadare and Adebanwi 2010). Although such a totalizing theory of power lacks the 'thick description' that acknowledges the variety of feelings, desires, and motives within a group, Marshall's (2009) analysis does provide interesting clues for how religious practices in The Brook Churchfrom its more liberal dress sense, to lively worship music, to biblical passages about man being made in God's image-are internalised by marginalised young women, making them ready to overcome both spiritually and socially.

Examining the attractions of Pentecostalism for a marginalised social group such as young women, I argue the need to understand how imbibing religious rhetoric and practising religion changes perceptions of the current self and projections of future possibilities. The discussion begins by detailing The Brook Church's history in order to shed light on the doctrine underscoring the religious rhetoric and action with which young women engage at the church. Examining how young women become church members at The Brook Church and the subsequent changes they experience, the second section frames religious action in a discussion of learning religion. The final section looks more explicitly at what The Brook Church's doctrine and practices mean for young women in particular, discussing how attending the church has changed some young women's outlook. The data was collected during fifteen months of doctoral fieldwork in Calabar. During this time I regularly attended The Brook Church services and programmes for six months, undertaking the Foundation Course to become a church member. My knowledge of the church, and wider religious scene in Calabar, is supported by interviews with Pastor Ose and young women in the church as well as other pastors and young women, predominantly university students and graduates in their twenties.

\section{'On Purpose, Manifesting Zoe': The Brook Church}

The Brook Church's doctrine and ethos play an important part in the making of new religious subjectivities, and by extension how young women come to 
view themselves and their ambitions for the future. With the motto 'On purpose, manifesting Zoe', The Brook Church is dedicated to excellence, intention, and aspiration for achievement in life, and to preparation of the self through God. It is believed that giving one's life to Christ at The Brook Church, or becoming a member there points to an eternal and bountiful life through Christ. As many young women in Calabar acknowledge, there is something 'unique' and 'classy' about The Brook Church, and Pastor Ose, the church's founder and head pastor, is acknowledged as embodying this ethos. His sound spiritual and business acumen, combined with hesitance to flaunt his wealth, have earned him a reputation for integrity and having a powerful presence of God. Likewise, his wife is recognised for her humility and spiritual strength; while she plays an important role as leader of the children's church and by giving marriage counselling, she never takes centre stage. Indeed, unlike other pastors and spouses, Pastor Ose and his wife shy away from the limelight; rather than advertising themselves as celebrities on billboards around Calabar, they advertise their ministerial charge through the actions and images of their church members. As one student in her twenties who had recently joined the church stated, 'I think that Pastor Ose is going places. He's gifted. What you get [at The Brook Church] is what you cannot get in any places.'

Originating from outside Calabar, Pastor Ose had not known Christ all his life. As he described, he was 'born a sinner'. It was while he lived and did business in Port Harcourt in the early 1990s that he decided he would like to start attending church. Telling me of his life history, he explained, 'I needed to get my bearings correctly.' Attending a church by his house, Pastor Ose was instantly struck by the message and answered the altar call. After 'giving his life to Christ' that first day at Christ Chapel International Church, his spiritual journey began, which saw the head pastor giving him responsibilities in the church. Fulfilling these duties well, he was asked to move to Owerri to become an auxiliary pastor. After a short while another opening came up, and he was moved to Calabar. Although the Calabar position was supposed to be temporary, his congregation requested that Christ Chapel International Church keep him. On this recommendation, Pastor Ose continued his posting for a few more years.

On 24 August 2001 at precisely 2:40 p.m., Pastor Ose experienced a revelation. Reading a book on pneumatology in his room, ${ }^{2}$ he found himself sobbing on the ground and praying in tongues. By the time he managed to get up some time later, he had the urge to pen down a short passage, which became the foundation of The Brook Church and which is kept on file in his office in the church building. It is not uncommon for pastors to tell of divine revelations in dreams and trances whereby they have been informed of their 
abilities to preach and guide others, or instructed to found a church (cf. Pype 2012; Werbner 2011). Such histories can tell us a great deal about a church's core values. As Pastor Ose read out the passage, which was littered with references to 'amazing manifestations', 'unusual anointing', and 'increasing productivity', I was struck by the fact that it never mentioned instances of doubt or fear. Pastor Ose's revelation simply asserted the almighty works produced only through God.

Furthermore, that Pastor Ose was keen for me to note the date and time of this revelation, and the fact that this revelation came eighteen months prior to the materialisation of his church, speaks directly to the church's preoccupation with time and timeliness. Coupled with Pastor Ose's initial decision in Port Harcourt to change the direction of his life, the history of The Brook Church exemplifies its ethos of management of the self and of time: knowing the self while developing a personal partnership with God, and preparing the self for personal success that can only be delivered by God's grace. Of course, Pastor Ose's spiritual life has not gone unnoticed by young female congregants, who see his current leadership role as testament to his faith and God's ability to deliver. As one young woman stated about her 'classy' pastor, 'I know it's taken a lot for him to get to that level but it's worth it.' These ideas of surety and timeliness are essential to how The Brook Church's doctrine allows young women to believe in their personal ambitions and maintain hope that these aspirations will be realised.

The first meeting for The Brook Church in 2002 was held in one of Calabar's premier hotels, already hinting at Pastor Ose's social capital. Coincidentally next to the University of Calabar's medical student hostel, the first church venue shaped the church membership — not only has there always been a strong student fellowship, but now, a decade on, many of the members are practising doctors or professionals, and members generally have or aspire to having status. After relocating to another hotel then renting an event hall, the church finally moved into its permanent church site in May 2007, where close to a thousand worshippers can attend. Despite its popularity and good reputation in the city, The Brook Church's expansion has been slow. Its second branch was founded in Owerri in 2011, and by the end of my doctoral fieldwork in 2012 there were plans to start four additional branches in Calabar. The main reason for this was that, as what Pastor Ose labelled a 'discipling church', he wanted these additional branches to be led by pastors grown from The Brook Church so that they had already imbibed the church's doctrine and ethos before reaching out to others. While the church services had been recorded and sold on CDs for some time, plans were also underway to broadcast on radio and satellite television, as well as stream services on the Internet. It has taken time and 
patience for the church to start reaching out to the world, and this has been very deliberate. Pastor Ose explained, 'I never wanted to run without a direction. I never wanted to run without any sense of destination.'

Such success, forward thinking, and uniqueness were no less apparent in the church's teachings. For instance, the very first Sunday I attended was a special family programme introduced by the Children's Church. Zealously mimicking Pastor Ose in their role play, the children standing on stage preached, 'God can do anything for you; everyday you need to trust God.' Pastor Ose then took to the stage and continued with his own message titled 'Winning with Grace'. While the church exuded wealth in its physical structure, its clever branding, the pastors' iPads, and its well-dressed congregation, it did not speak about prosperity explicitly (cf. Gifford 1998). The pastor spoke of behaviour, but he was not delivering the righteousness doctrine of the Deeper Life Bible Church (cf. Marshall 1991; Ojo 1988), nor did he focus only on miracles, although God was acknowledged as the only being capable of doing the miraculous. While Marshall (2009) outlines the tension between the 'holiness' or 'righteousness' and the 'prosperity' doctrines, the teachings of The Brook Church underscore not only the multiple doctrinal interpretations within Nigerian Pentecostalism but possibly point towards the emergence of a new recognisable trend focusing on the positive. Worshipping at The Brook Church gives anyone the spiritual qualification of having 'headship', the characteristic of being ahead in life, the ability to make decisions as a leader, and the knowledge that 'With God, all things are possible'.

Reiterating The Brook Church's ethos, I suggest that the church imparts a 'doctrine of Zoe'. This, as Zoe suggests, is an inherently life-affirming message that illuminates the bountiful existence the Pentecostal subject is entitled to enjoy and command. The 'prosperity doctrine' undoubtedly harbours the same sentiments of entitlement and abundance through Christ, yet the Greek word Zoe differs in its emphasis on eternal life as opposed to life on this earth, referred to in the New Testament by the Greek word Psuche. ${ }^{3}$ In line with how Pentecostalism is acknowledged to map onto the local (cf. Meyer 1992, 1998; Robbins 2004; Engelke 2010), Zoe refers to the immortal spiritual realm that determines what happens in the mortal physical realm. By subscribing to The Brook Church's doctrine, a worshipper focuses on the intertwining of the spiritual and the physical: how to view oneself as a supernatural being in a human body, and ultimately how to harness the power of the Holy Spirit in order to take control of one's life.

From the latter we can also infer how Zoe refers to the much-used concept of destiny. Traditional Efik cosmology in Calabar uses a number of concepts to define destiny, which ultimately denote one's life course predetermined by 
links to deities and ancestors. Akaya refers to a spiritual covenant made before birth with a creator figure, in essence a promise or vow signifying an exchange of rights. For instance, in exchange for giving oneself to a deity and vowing to worship the deity throughout one's life, the deity promises to bestow fortune on the individual. This understanding of an individual being moulded by a spiritual force throughout its physical life — from birth to death—links the concepts of destiny or fate with $u w a$ (life, creation, universe) and obot (creator, creation). One's circumstances in life - health, wealth, and inheritance-are also determined by one's bloodline or ancestral birth (emana). This links an individual to the moral successes or failings that replicate over generations, and hence also with any spiritual covenants made by ancestors to initiate such occurrences. When talking about what one's life is destined for due to spiritual and ancestral birthrights, the future is often referred to as ini iso (literally 'time ahead').

Today, in the ethnically and linguistically mixed Christian Calabar, the English word 'destiny' is used to refer to God's plan for one's life. Being born through and identifying with Christ, and being born into God's family, a Christian's destiny can only be one of aggrandisement and accruing entitlements, as is illustrated by the commonly used phrase 'destiny of greatness'. Any failings in a Christian's life are often believed to spawn from an unknown and unbroken covenant with a diabolic deity or one's heathen ancestors. Unlike other churches that openly advertise their ability to help Christians spiritually battle with 'generational curses', The Brook Church is careful to not stress the idea of unknown covenants preventing one's fortunes from being realised. Subscribing to the doctrine of Zoe should demonstrate total identification with, dedication to, and trust in God, overruling any other belief that another force can affect one's life course. The church's businesslike semantics, epitomised in its three-day annual 'Purpose and Destiny Summit', are pertinent: one's rightful future can only be attained through careful planning, consultation, and purposeful action with God.

Hence accompanying the emphasis on the cornucopian life the worshipper can enjoy, Zoe stresses the importance of action and management of the self. It is this strict insistence on having direction and patience, and only acting when the time is right for success that sets The Brook Church apart from other larger Pentecostal churches in Nigeria that emphasise leadership, such as Winners Chapel (Living Faith Church). Such an understanding of selfmanagement with God in which time and direction are internalised in the body through religious action also expands on existing analyses of Pentecostalism's use of time: from the born-again dialectic of the past as a problem in the present (Meyer 1998); to Pentecostalism changing personal trajectories of time, 
especially in contestation with state rhetoric (van Dijk 1998, 2001); to the millennialist narrative of urgent spiritual warfare in the end-time (Marshall 2009); and also to the recognition of Pentecostalism as a future-oriented religion, mending a country's torn social and political fabric (Piot 2010).

This eternal life of abundance is inextricably linked to ideas of the Christian subject, not only in terms of their relationship with God but also concerning their position within society. Crucially, The Brook Church's congregants are not only taught to view themselves as leaders in life but actively assert the belief in their own authority and entitlements in each church service. The best exemplar of how the church's doctrine plays out in action is seen in a set of twelve motivational bullet points. Introduced on the first Sunday of 2012 when ushers handed out glossy cards titled 'Confessions for 2012', these bullet points are read out loud by the congregation at the beginning of each service (see Fig. 1).

Far from acting as a Catholic confessional, the above statements are declarations of faith to follow the Protestant tradition. These statements are an assertion of a doctrine that bears witness to the superlative nature of God and worshipper. Admittedly, there is something immensely powerful about a thousand-strong congregation reciting these bullet points in unison, culminating in a forceful 'Surely I will arrive at God's destination for my life!' Indeed, as with Pastor Ose's revelation in 2001, these are not words of fear and desperation, or for demanding God's protection, but of assurance and confidence. There is no mention of current struggles, only of God's divine plan for the individual. The only strategy of breaching the gulf between what is and what God decrees is through the process of identifying the self in Christ. Yet these confessions are not just statements of faith but, following Csordas's (1997) work on the phenomenology of ritual language where the 'I' allows the speaker to believe the 'divine other' is speaking to them directly, these confessions can be viewed as prophesies for the individual. Through determined recitation, the worshipper wills him/herself to embody the phrases they announce. Hence these confessions are pertinent to the idea that religious action is central to the development and understanding of the self.

These details of The Brook Church's history and doctrine highlight the necessity of examining an individual church's development in order to understand how Pentecostalism can affect young women's lives. Illuminated in Pastor Ose's businesslike outlook and rise as an anointed man of God, the slow and purposeful growth of the church, and the constant message of leadership and abundance in life, the doctrine of Zoe is very much about direction and management of the self. Yet as the above has shown, this doctrine is also all encompassing for worshippers who change as they worship at the church. As one church member, a medical student in her early twenties, explained about 


\section{CONFESSIONS FOR 2012.}

- I am the temple of God's unlimited Spirit, reloaded for Glory and created for mighty works of grace.

- I was born for dominion and headship in life.

- I am the planting of the Lord and the righteousness of God in Christ.

- I am fruitful and highly productive.

- As a branch in the vine does not struggle to be fruitful. So I bear fruit and achieve results with ease in all aspects of my life.

- Daily my horn of influence and authority is anointed with fresh oil.

- I engage the mind of Christ in me, for answers to any challenge that confronts me.

- I walk in the fullness of God, experiencing grace upon grace daily.

- I influence lives with the grace of God, everywhere I go.

- I am focused on the living hope provided for me by the blood of the Lamb in Christ.

- As I give voice to the word of God, I receive the ministry of angels assigned to me now.

- Surely I will arrive at God's destination for my life.

$$
\text { TheBrook }
$$

FIGURE 1 Photocopy of the Confessions card handed out to worshippers at The Brook Church.

the church, "[The] Brook Church kind of moulds you. If you come to the church and you're a person who doesn't know how to dress, with time, you just adjust. Nobody has to tell you, you just adjust.' The church's discourses and practices that focus on the self ultimately fashion new religious subjects. Yet this young 
woman's words also give us an understanding that the practices internalised by the worshipper may not be explained or enforced by others, but picking up on them is not necessarily such a subconscious process as Marshall's (2009) Foucauldian analysis might have us believe.

\section{'Come Drink at the Brook': Imbibing Pentecostal Practice}

With its encouragement of a positive mind-set, The Brook Church teaches young women to re-evaluate their self-worth and focus on personal success. ${ }^{4}$ As exemplified in the opening vignette, Calabar's Pentecostal movement is full of programmes offering spiritual advice. Young women often attended these programmes to learn how to develop specific religious techniques such as praying in tongues or fasting, or to find out about certain themes such as 'singlehood', business, or 'generational curses'. The programmes also help Christians gain strength at certain times of intensified spiritual activity. For instance, the so-called 'Mber Months' from September to December mark a period when diabolic spirits are believed to be busy preparing for the end of the year. Since Calabar's residents must make money ahead of end-of-year celebrations, there is the understanding that some call on occult powers to make quick fortunes at the expense of others' lives. During these treacherous months programmes are held to help Christians ward off malevolent spiritual attacks. Conversely, programmes around Easter are intended for worshippers to benefit from the increased proximity of the Holy Spirit on 'Resurrection Sunday', allowing Christians to harness the spiritual power that enabled Christ to be raised from death. New Year's Eve, known as 'Cross-Over Night', is perhaps the most important church programme of the year. Held at night when the barrier between the physical and spiritual realms is believed to be weaker, even the city's lessregular churchgoers see the need to thank God for seeing them through the year and to ask for greater successes in the coming months.

While The Brook Church holds special programmes at these times of abnormal spiritual activity, young women primarily learn Pentecostal rhetoric and practices through their regular attendance at Sunday and midweek services. For instance, The Brook Church's Foundation Course allows one to become a full member of the church, and exemplifies how others, from Pastor Ose and his workers to other congregants, shape one's Pentecostal journey. ${ }^{5}$ Towards the end of every service, first-time worshippers are asked to raise their hands to identify themselves, before being asked to stand for a formal welcoming. A few members of the choir, Streams of Grace, come up to the stage to sing the 
lively Brook Church song, with the words projected onto the wall for everyone to join in, while ushers walk round to shake newcomers' hands and give them a welcome pack in a large white envelope. Those seated around the newcomers also take this opportunity to greet the new worshippers. These are common practices in Calabar's Pentecostal churches; however, The Brook Church's welcome is especially warm and energetic. It is difficult to not feel special and instantly part of the church family, as the song illustrates:

God has a plan for you

That's why He brought you here today

So glad you came

We love you

You should be a part of Zoe,

Yeah, yeah, yeah, yeah, yeah

So we say welcome to the brook

And we pray God's purpose for you

Here in The Brook Church

We are manifesting Zoe

We say

You should be a part of Zoe

Today

Feeling a part of The Brook Church family is only the first step in becoming a member. After being welcomed, newcomers are asked to meet with Pastor Ose after the service, where they are welcomed again and encouraged to start the Foundation Course. It is only through attending all eight classes, meeting with Pastor Ose again in the final week in a question and answer session about The Brook Church, and then taking an exam-as incentive, the first in the class receives 5,000 naira (roughly £20) — that one can become a full church member eligible to join a working group. Just as Pastor Ose states that he wants his pastors for new church branches to be 'brought up' in The Brook Church, learning the church's doctrine is imperative not only for categorical membership but for the acting out of the church doctrine in service to God, such as singing in the choir, serving as an usher, or cleaning the church. Doctrine is imparted, imbibed by the individual, and incorporated into their actions not only to answer spiritual problems (cf. Marshall 2009) but also, as will be discussed, to continue the education process by evangelising others through action (cf. Berliner and Sarro 2007).

The Foundation Course is a cleverly constructed process of self-realisation, learning how to understand one's place in God's kingdom, to identify oneself 
through God, and to live by the Word of God. The course takes eight weeks to complete and is held directly after Sunday services. Students are encouraged to not miss any of the classes so that they can progress with the same group leader, a member of the church's counselling department. The counsellor is there to answer any questions both during and outside class; my own course counsellor gave me his phone number in case I needed guidance between services. Incidentally, although young women in Calabar often regard church as a spiritual rather than social community, I became firm friends with the two young women in my small group. Just as Houseman (2007) emphasises the importance of empathy in religious education, joining the Foundation Course was an integral part of belonging in the church. I was surprised by how many people not only noticed but also congratulated me on starting the course, welcoming me further into the church family.

Each week of the course follows a different topic, developing the belief in-and possibilities that come out of-being 'a supernatural being in a human body'. Our counsellor took us through printed handouts, delegating Bible passages to be read out loud before asking us what we understood by the message. Despite the extensive number of Bible passages, each class had a succinct focus. For instance, in discussing Christian identity, the first couple of classes taught how being Born Again erases all sin, and how identifying with Christ bestows a 'dual citizenship' on earth and with God. In understanding Pentecostalism's envisaged modernity, The Brook Church's lexicon of dual citizenship is imperative for understanding authority, rights, and entitlements. The born-again individual is no longer akin to Mbembe and Roitman's (1995) struggling subject but holds a citizenship of divine access by knowing God. As we were taught, 'Your level of identification determines your strength and personality as a believer in Christ.'

Subsequent lessons focused on the means of exercising these entitlements. Prayer, the breath of the 'spirit man' (similar to one's conscience), was taught not as a request for God's help but as confirmation of God's work already done. Understanding how to fulfil destinies, our personal ambitions, we were taught to internalise the Holy Spirit; the following week focused on this internalisation through the explanation that 'Gifts of the Spirit' were not conduct but part of the worshipper. The final weeks focused on knowing Christ in order to command authority and bring triumph in life. As with the passage Pastor Ose penned down for the doctrinal underpinnings of the church, the Foundation Course only teaches the positives of identifying with Christ. Worshippers are taught that although they are entitled to demand anything in life, the concepts of Divine Timing and Divine Intervention mean that it is ultimately God who decides when and how successes are bestowed; the challenge is to know 
oneself well so that one's demands match one's fate as decided by God. This task of knowing one's true calling in life is complicated by worshippers' belief that their destiny can be 'stolen' by others or that diabolic spirits can potentially intercept their entitled successes. Although the church acknowledges the existence of diabolic spirits such as witches and local marine spirits, The Brook Church's spiritual practices only focus on the positive qualities one receives by identifying with Christ. It goes unsaid, but worshippers do also visit other churches or prayer ministries if they feel the need to spiritually battle with the occult.

Hence in asking how The Brook Church's teachings help the growth of young women as Christian subjects, it is apparent that their elevated self-perception and belief in success is encouraged by both the empathy received from others and also by internalising religious rhetoric and practice. While the counsellor's guidance through the Foundation Course is crucial for feeling close to the church community, the exam at the end of the course is an excellent example of how young women must imbibe the church's doctrine in full in order to be recognised as and receive the rights of a Brook Church member.

Moreover, the way in which The Brook Church provides a rich analysis of the Bible gives young women in particular a certain confidence in what they are being taught, and hence how to implement it. As one young woman, a masters student at the University of Calabar, explained, 'The foundation class is quite educative. It is making me know more about the Word of God. There are certain things that I wasn't really savvy about but it's making things easier for me.' The young woman had grown up in Deeper Life Bible Church, although her family left this ascetic and, as she described, 'straight' church after her mother watched a Pentecostal pastor evangelise on television. With a renewed sense of spiritual enrichment, the family tried a few Charismatic churches before settling at Calabar's largest Winners Chapel branch, which was near their family home. The young woman became a dedicated member, enjoying the sermons and committing her spiritual service to the choir. With this strong Christian background it was therefore surprising to hear how much she benefited from The Brook Church's initial teachings, yet other young women coming from other churches such as Christ Embassy and Redeemed Christian Church of God also echoed this view. One young woman described how Pastor Ose really 'digs deep' to explain how the Bible is applicable to her life, while another explained, 'I really achieved from [Pastor Ose]. He will teach the word of God and the guidelines of what to go through.... Unlike other pastors who will want to pray-they want to pray, Pastor Ose will teach.' While such personal testimonies highlight how religious action, such as learn- 
ing the Bible, moulds the religious self, it also demonstrates the difficulties of reifying young women's religious experiences within Calabar's diverse Pentecostal scene.

One of the most significant rights a worshipper receives on completing the Foundation Course is the chance to join one of the church's working groups, which include Streams of Grace (choir), Vineyard (cleaners), Acorn Circle (prayer group), Reflections (dance and drama), Herald (ushers), and Armour Bearers (or PPA for Pastors' Personal Assistants). These groups act as support staff to Pastor Ose, and new members choose which to join according to their own abilities or are sometimes scouted by members of the group. While these are managerial groups, the emphasis is purely spiritual. The fact that only graduates of the Foundation Course can join these groups speaks to Pastor Ose's vision of having a 'discipling church', the notion that worshippers must be indoctrinated into the church before they can take up certain positions of authority and influence. Yet joining a working group is also an intrinsic part of Pentecostal worship in the ways in which the worshipper uses their believed 'God-given talents' to minister to others. Young women not only feel important that their spirituality can aid others' worship, but use these positions in the church to further develop their spiritual talent. While this underscores the notion of how spiritual action and empathy from others moulds the religious subject, being an active member of a working group is particularly important for young women's self-development in view of the opportunities these groups present.

For instance, soon after she started worshipping at the church one young woman who took the Foundation Course with me was approached by the head of Pastor's Personal Assistants. The man, who was not only well respected in the church but also well connected in wider society, asked the young woman whether she attended the church, and then whether she had completed the Foundation Course before asking her to join PPA. My friend did not know the exact reason for this invitation, although one reasonable guess could be that her outward appearance already suggested she both looked the part and was capable of organising Pastor Ose's affairs, but she was extremely flattered by this conversation. Most of all, she relished the fact that she, an undergraduate student still living with her mother and younger brother, had not only been approached by such a man but also that he thought she could work alongside him and Pastor Ose. As she explained, 'I felt happy because I have not gone anywhere where an overall [authoritative] person comes to talk to you. I felt excited, and felt that I would love to join PPA.' Her desire to join PPA increased further when she learned that the church helped church workers 
acquire suitable wardrobes-in this case suits - to carry out their responsibilities. Just as Marshall (1991) outlines how marginalised youth in Nigeria can use Pentecostalism to fight social iniquity with spirituality, young female members of The Brook Church who are normally disenfranchised from (particularly male) patronage networks are able to use spiritual fervour to reverse social standings.

For young women the opportunities presented by working groups are not just about being recognised by influential people but also about selfimprovement. This became apparent as I got to know Legbel, a medical student and a member of Pastor's Personal Assistants. Brought up a Catholic, she started attending a Charismatic fellowship when she came to Calabar for university. Enlivened by Pentecostal worship and the care shown for its congregants, she joined The Brook Church but had to stop because of the high transportation costs. While she enjoyed worshipping at another student church for some time, she finally returned to The Brook Church, knowing that she wanted to join the church protocol team in order to learn new skills, the top priority being to develop patience. As she said about herself, 'I know I have never been this kind of patient type before now. You can't do anything to me and you just get away with it. Secondly, I might just be very blunt and tell you there and then, and I don't really care about the person so much. I just needed to study some things and learn.' Explaining how PPA members must look after Pastor Ose and his wife from the church to the home-such as cooking for their guests, collecting dry cleaning, accompanying them when they travel, and praying for the church-Legbel acknowledged that she had become more patient through the long hours of spiritual duty. Legbel had acquired this patience mainly because she was often working alongside her seniors, to whom she had to show respect. She went on to explain a likely scenario in which she would be called to a PPA meeting and asked to give money for a forthcoming wedding in the church. As a student with a small job that rarely paid, she admitted she would not be able to pay such a fee, yet being a member of PPA had taught her to bite her tongue and not answer back when her elders scolded her for not contributing as required. Rather philosophically, Legbel added, 'Sometimes [the scolding] might be like an advice-somehow you just pick some things and receive it, and leave the rubbish.'

Here we may revisit the idea of empathy in religious education (Houseman 2007), highlighting how others are integral to the individual's religious journey (see also Daswani 2011; Pype 2011; Werbner 2011). A further demonstration of this comes through the complaints of young women, such as Legbel, that relationships within these working groups could sometimes be acrimonious. It 
was not only the positive encouragement from others that made young women focus on the ideas of self-worth expounded by the church's doctrine and Confessions, sometimes another's misconduct — such as an older man exerting too much authority or another girl's jealousy-made them remember that they should view themselves as righteous leaders. Beyond self-improvement, Legbel never explicitly explained how being a member of PPA could change her life outside church. It seemed that being a member of P PA was more of a way for Legbel to learn how to remember her value. Echoing both the Sisters' Talk and the Confessions, Legbel had to look inwards and identify with greatness in order to cope with being a young woman in a highly conservative and patriarchal society.

Christian education is of course nothing new in Africa. Early missionaries changed emic worldviews (e.g., Comaroff and Comaroff 1991; Horton 1971; Mudimbe 1988); and more recently the rise of Pentecostalism across Africa has connected the continent to a rapidly expanding spiritual network (e.g., Marshall-Fratani 1998; Coleman 2000). Yet more than just creating new categories of people (e.g., Bastian 2000; Peel 2000, 2002), the above has shown how The Brook Church creates religious subjectivities that are continually moulded through action and engagement with others. Crucially for young women, as they are moulded in church to believe in and aim for success and leadership, they are also making an impact on their lives outside the church. Explaining another aspect of Zoe, Pastor Ose stated that just as people should not live their lives in church, neither should Christianity stop at the church door-a notion that echoes analyses linking contemporary religious movements in Africa to the creation of jobs and to shifts in local and global economies, especially where such religions carve out new moral attitudes (see for instance Gifford 1998; Maxwell 1998; Meagher 2009). While I question the extent to which Pentecostalism does create alternative spaces for young women beyond the church (cf. Bochow and van Dijk 2012), the above highlights how young women at The Brook Church are offered new opportunities and aim to use this spiritual action for self-development.

\section{Building Confidence: Looking Inwards, Going Forwards}

The Brook Church's doctrine of Zoe emphasising eternal entitlement through timely preparation of the self, its Foundation Class teaching self-identification with Christ as a leader, and the working groups for spiritually strong church members all illustrate how Pentecostal rhetoric and action mould religious 
subjects aiming for success. Yet more than this, these religious practices are inherently about feeling and acting positively. From the building's and congregants' material wealth to its self-promoting Confessions and its heartening welcome song, The Brook Church is reminiscent of Soothill's analysis of Ghanaian Pentecostalism in which "feeling good" and "positive thinking" take centre stage' $(2007,70)$. As young women frequently told me, often confined to the house with either chores to do or with a lack of electricity or money to entertain themselves, they would feel 'depressed'. It appeared that church was the only thing that could make them feel better. As one young woman explained about attending The Brook Church: 'You just forget about whatever you were thinking about. I don't bother myself because I now know that whatever God has in store for me, that is what is going to happen.' While Pentecostal analyses have touched on the teaching of emotions inside the church (e.g., Soothill 2007; van de Kamp 2011; Pearce 2012), it is interesting to consider how the positive teaching and religious actions of The Brook Church actually help young women view themselves and their ambitions differently beyond church.

For instance, I got to know Debbie, a second-year university undergraduate, through the Foundation Course. She had grown up in the Celestial Church of Christ — a 'white garment' AIC—-before moving to the Apostolic Church, and later a small Pentecostal church called Christ Healing Ministry. After Debbie's father died while she was in her late teens, Debbie's mother stopped going to church in order to work on Sundays, and Debbie, still living at home but now free from attending a family church, decided to join a branch of the Redeemed Christian Church of God. While she liked the church's short services and explanation of the Bible, she admitted that she never found 'inner peace', the feeling of all stresses being lifted. It was when her family moved and her neighbour asked if she would like to accompany him to The Brook Church that she saw her spiritual life change.

Hearing Pastor Ose's teaching and the uplifting music from Streams of Grace-incidentally described as 'Pastor's right hand' in view of their importance to congregants' worship experience-Debbie felt excited that she had found 'that inner peace inside'. She explained how she soon began to realise what she wanted in life and what her purpose was. Indeed, her words began to explicitly echo what Pastor Ose preached about locating one's destination in life and having direction for arriving at it. As she explained, 'I knew what was going on-I mean what I am going to do, what kind of person I am going to be, whether it will affect my family positively or negatively.' For Debbie this was not a feeling of purpose, but a concretised plan of action. As she told me on a 
number of occasions, she had not been entirely convinced that her university degree was the best thing for her long-term achievement:

I knew I was lacking but I didn't really know what.... As in, [if I had been at The] Brook Church [when I applied for university], I don't think I would have been in physiology now. I have always liked medicine and surgery. My parents have always been supportive. If I had been in [The] Brook Church, I would have realised that. I would have been more matured. I'm really getting matured from [The] Brook Church-the way I am thinking, the way I talk sometimes. I'm really getting more grown up from The Brook Church.

A few months after joining The Brook Church, Debbie made a plan to move to a better university in a neighbouring state to study medicine. Planning for the matriculation exams and to move in with an aunt near the new university, Debbie felt confident that her life was on track. As she explained, Pastor Ose had not just taught her how to know what she wanted but also had assured her to trust in God: 'Pastor Ose has helped me realise that my faith works for me. I am the owner of my destiny — nobody [else] owns it.' While analyses highlight how Pentecostalism provides information that young women cannot access easily in their wider lives, particularly on relationships (e.g., Bochow and van Dijk 2012; Pype 2012), it appears the crucial void The Brook Church filled for Debbie was belief in herself. However, when I caught up with her some months later, she explained how her plans had fallen apart. Her university exam scripts had gone missing - one of the many common administrative errors that plague university life in Nigeria-meaning that her grade had fallen and she had been forced to drop out of her studies. Feeling incredibly down about this, she described how she barely left the house and rarely went to church anymore. It went without saying that she had abandoned all plans of moving to a new university. Hence while young women do gain self-confidence from The Brook Church to carry out their ambitions, they remain at the mercies of the numerous insecurities characterising Nigerian life. Moreover, just as it can be built through religious action, confidence can also be lost if religious practice stops.

How young women must negotiate their Christian lives with the struggles of life in a Nigerian city also speaks to Patience's story. Also joining the church at the same time as me, Patience stood out because a male 'friend' always accompanied her, who was later introduced to me as her fiancé. She explained that they were both very depressed because he had recently lost his job, and, with 
only her small business selling clothes to friends, finances were tight for both of them. One morning her fiancé told her about a dream in which he saw The Brook Church. When one of the church shuttle buses passed her that morning on the road she knew it was a sign to join the church, signalling that it is not only pastors who have spiritual revelations. They were initially attracted to the church due to Pastor Ose's preaching about self-management and the church's praise and worship (music), but the couple soon found themselves under the wing of Pastor Ose's wife. While Patience did not see the need to rush into marriage in view of their lack of finances, Pastor Ose's wife encouraged them to prepare themselves seriously for marriage. On her own accord, Patience soon moved out of the accommodation she shared with her fiancé, although, without money, she could only sleep on friends' floors. Telling me how uncomfortable her situation was, she highlighted that following Pentecostal rhetoric and practice is not always easy for young women. While Patience did feel her spirituality uplifted at The Brook Church, recognising that the church had helped her focus on building her small business, her life outside church was not without difficulty.

The stories of Debbie and Patience illustrate how attending Pentecostal churches for young women in Calabar was not always directly linked to marriage prospects. Yet marriage counselling headed by Pastor Ose's wife is a fundamental part of The Brook Church's 'discipling' ethos, dovetailing not only the analyses mentioned above (Bochow and van Dijk 2012; Frahm-Arp 2012; Pearce 2012) but also others from around Africa: see Soothill (2007) for an analysis of gender complementarity in Ghanaian Pentecostalism; Mate's (2002) analysis of wives as spiritual support in Zimbabwean Pentecostalism; and van de Kamp's (2011) examination of how violent acts of spiritual warfare counter 'spirit spouses' affecting Mozambican women's intimate relationships. For instance, Jane had just married when I met her at The Brook Church. She explained that she had been engaged before to her first love, but that he was a 'dropout' who had never finished university. Guided by 'her pastor' (a family friend) and aided by a prayer fellowship, the university graduate left her fiancé in order to find someone with drive and the means to support her ambitions. She quickly met someone else and got engaged within two days. They married two years later. Judging his character on their initial meeting and knowing that he would be capable of looking after her as a wife, her story spoke to the Sisters' Talk programme whereby a girl should only pursue projects and relationships that add value to her life.

Reading from notes she had made in her jotter pad, Jane went on to detail the guidance she had received from The Brook Church in the eight weeks 
leading up to her marriage. Starting with the 'Three Hands of Marriage'companionship, fellowship, and multiplications-The Brook Church teaches that a married woman should be a homemaker for her decisive and responsible husband. While such an idea resonates with salient Pentecostal ideas of the wife as the spiritual support in marriage (e.g., Mate 2002; Soothill 2007), The Brook Church's doctrine of management of the self through God plays a crucial part in the success of the future marriage. Brides-to-be must be aware of how they communicate with their husbands, how they manage finances, how they relate to their wider family, and how they manage their body (incidentally, showing a negative pregnancy test is the final step of marriage counselling). What really struck Jane was the way she was taught to manage her less-attractive personality traits, in particular her temper. Becoming more self-aware, and also realising her feminine spirituality, Jane explained that she could have a productive marriage by knowing that she did not need to 'flare up' but simply know her role as wife, trust in God, and submit to her husband. While Jane's story highlights how, right up to their marriage, young women at The Brook Church are taught to know and manage themselves through God in order to succeed, Jane's final comment about submission in marriage makes even more pertinent Pastor Ose's demand that young women must realise their purpose and marry accordingly.

\section{Conclusion}

Focusing on one church in Calabar, I have not sought to reify young women's engagement with Pentecostalism in Africa but rather to open up a discussion on how the movement can be attractive to this particularly marginalised group. Throughout the discussion I have argued how learning religious rhetoric and doctrine moulds new subjectivities. At The Brook Church, with its ethos of eternal abundance, entitlement, and success, young women are taught to identify with and manage themselves through God. Through regular worship at The Brook Church young women come to view themselves as leaders with the conviction that they are more able to navigate the social arenas in which they are traditionally marginalised. The Brook Church's focus on knowing and becoming the purposeful and successful self, particularly highlighted in Debbie's attempts to realise her aspirations, leads us to question how Pentecostalism allows young women to view themselves as sisters, daughters, friends, students, and colleagues. Such questions allow us to move beyond the current focus of sexuality and conjugality in understanding young women's attraction 
to Pentecostalism. Moreover, these questions allow us to acknowledge that just as Pentecostal churches do not necessarily reconfigure social norms outside the church, neither is the empowerment young women feel within the church completely removed from patriarchy or conservatism.

Framing Pentecostal worship as an individual project of autobiographical enlargement also presents a paradox: the need for others in succeeding on a personal religious journey. The Brook Church teaches young women to know themselves well and to trust in God to realise their aspirations, yet part of the appeal of Pentecostal churches is their ability to include young women socially. Pastor Ose is a role model but also available for private counselling, the welcome song and Foundation Course make newcomers feel instantly loved and included, and the working groups allow members to simultaneously strengthen their spiritual talents and check themselves by others' behaviour. Hence in asking how worship practices mould religious subjectivities aimed at overcoming the social and political cleavages of power, the case study presented here calls for scholars to better understand individuals' awareness of self and emotion, empathy, and social obligation as they practise religion.

\section{Acknowledgments}

This research was funded by a studentship from the Economic and Social Research Council UK (grant number Es/I903887/1).

\section{References}

Adogame, Afe. 2010. 'How God became a Nigerian: Religious Impulse and the Unfolding of a Nation'. Journal of Contemporary African Studies 28.4, 479-498.

Bastian, Misty. 2000. 'Young Converts: Christian Missions, Gender and Youth in Onitsha, Nigeria 1880-1929'. Anthropological Quarterly 73·3, 145-158.

Berliner, David, and Ramon Sarro. 2007. 'On Learning Religion: An Introduction'. In David Berliner and Ramon Sarro (eds.), Learning Religion: Anthropological Approaches. New York and Oxford: Berghahn Books, 1-20.

Bochow, Astrid, and Rijk Van Dijk. 2012. 'Christian Creations of New Spaces of Sexuality, Reproduction, and Relationships in Africa: Exploring Faith and Religious Heterotopia'. Journal of Religion in Africa 42.4, 325-344.

Cole, Jennifer. 2010. Sex and Salvation: Imagining the future in Madagascar. Chicago and London: University of Chicago Press. 
Coleman, Simon. 2011. 'Introduction: Negotiating Personhood in African Christianities'. Journal of Religion in Africa 41, 243-255.

- 2000. The Globalisation of Charismatic Christianity: Spreading the Gospel of Prosperity. Cambridge: Cambridge University Press.

Comaroff, Jean, and John Comaroff. 1991. Of Revelation and Revolution: Christianity, Colonialism and Consciousness in South Africa. Chicago and London: University of Chicago Press.

Csordas, Thomas J. 1997. Language, Charisma, and Creativity: The Ritual Life of a Religious Movement. Berkeley: University of California Press.

Daswani, Girish. 2011. '(In-)Dividual Pentecostals in Ghana'. Journal of Religion in Africa 41.3, 256-279.

Engelke, Matthew. 2010. 'Past Pentecostalism: Notes on Rupture, Realignment, and Everyday Life in Pentecostal and African Independent Churches'. Africa: Journal of the International African Institute 80.2, 177-199.

Frahm-Arp, Maria. 2012. 'Singleness, Sexuality, and Dream in Marriage'. Journal of Religion in Africa 42.4, 369-383.

Gifford, Paul. 1998. African Christianity: Its Public Role. London: Hurst \& Co.

Hackett, Rosalind I. J. 1989. Religion in Calabar: The Religious Life and History of a Nigerian Town. Berlin: Mouton de Gruyter.

Hetherington, Kevin. 1997. The Badlands of Modernity: Heterotopia and Social Ordering. London: Routledge.

Horton, Robin. 1971. 'African Conversion'. Africa: Journal of the International African Institute 41.2, 85-108.

Houseman, Michael. 2007. 'Menstrual Slaps and First Blood Celebrations: Inference, Simulation and the Learning of Ritual'. In David Berliner and Ramon Sarro (eds.), Learning Religion: Anthropological Approaches. New York and Oxford: Berghahn Books, 31-48.

Mahmood, Saba. 2005. Politics of Piety: The Islamic Revival and the Feminist Subject. Princeton, NJ and Oxford: Princeton University Press.

Marshall, Ruth. 2009. Political Spiritualities: The Pentecostal Revolution in Nigeria. Chicago and London: University of Chicago Press.

- 1991. 'Power in the Name of Jesus'. Review of African Political Economy 52, 21-37.

Marshall-Fratani, Ruth. 1998. 'Mediating the Global and Local of Nigerian Pentecostalism'. Journal of Religion in Africa 28.3, 278-315.

Mate, Rekopantswe. 2002. 'Wombs as God's Laboratories: Pentecostal Discourses of Femininity in Zimbabwe'. Africa: Journal of the International African Institute 72.4, 549-568.

Maxwell, David. 1998. “Delivered from the Spirit of Poverty?": Pentecostalism, Prosperity and Modernity in Zimbabwe'. Journal of Religion in Africa 28.3, $35^{0}-373$. 
Mbembe, Achille, and Janet Roitman. 1995. 'Figures of the Subject in Times of Crisis'. Public Culture 7.2, 323-352.

Meagher, Kate. 2009. 'Trading on Faith: Religious Movements and Informal Economic Governance in Nigeria'. Journal of Modern African Studies 47.3, 397-423.

Meyer, Birgit. 1998. "'Make a Complete Break with the Past": Memory and Postcolonial Modernity in Ghanaian Pentecostal Discourse'. Journal of Religion in Africa 28.3, 316-349.

— 1992. "If You Are a Devil, You Are a Witch and, If You Are a Witch, You Are a Devil": The Integration of "Pagan" Ideas into the Conceptual Universe of Ewe Christians in Southeastern Ghana'. Journal of Religion in Africa 22.2, 98-132.

Mudimbe, Valentin Y. 1988. The Invention of Africa: Gnosis, Philosophy, and the Order of Knowledge. Bloomington: Indiana University Press.

Obadare, Ebenezer, and Wale Adebanwi. 2010. Encountering the Nigerian State. Basingstoke: Palgrave Macmillan.

Offiong, Essien A. 2003. Pentecostalism in Nigeria: Calabar Experience 1970-1995. Calabar, Nigeria: Glad Tidings Press Ltd.

Ojo, Matthews A. 1988. 'Deeper Christian Life Ministry: A Case Study of the Charismatic Movements in Western Nigeria'. Journal of Religion in Africa 18.2, 141-162.

Pearce, Tolu Olu. 2012. 'Reconstructing Sexuality in the Shadow of Neoliberal Globalization: Investigating the Approach of Charismatic Churches in Southwestern Nigeria'. Journal of Religion in Africa 42.4, 345-368.

Peel, John D.Y. 2002. 'Gender in Yoruba Religious Change'. Journal of Religion in Africa $32.2,136-166$.

- 2000. Religious Encounter and the Making of the Yoruba. Bloomington: University of Indiana Press.

Piot, Charles D. 2010. Nostalgia for the Future: West Africa after the Cold War. Chicago, IL: University of Chicago Press.

Pype, Katrien. 2012. The Making of the Pentecostal Melodrama: Religion, Media, and Gender in Kinshasa. New York and Oxford: Berghahn.

- 2011. 'Confession cum Deliverance: In/Dividuality of the Subject among Kinshasa's Born-Again Christians'. Journal of Religion in Africa 41.3, 280-310.

Robbins, Joel. 2004. Becoming Sinners: Christianity + moral torment in a Papua New Guinea Society. Berkeley, Los Angeles, London: University of California Press.

Soothill, Jane E. 2007. Gender, Social Change and Spiritual Power: Charismatic Christianity in Ghana. Leiden and Boston: Brill.

Van de Kamp, Linda. 2011. 'Converting the Spirit Spouse: The Violent Transformation of the Pentecostal Female Body in Maputo, Mozambique'. Ethnos: Journal of Anthropology 76.4, 510-533.

Van Dijk, Rijk. 2001. 'Time and Transcultural Technologies of the Self in the Ghanaian Pentecostal Diaspora'. In André Corten and Ruth Marshall-Fratani (eds.), Between 
Babel \& Pentecost: Transnational Pentecostalism in Africa and Latin America. London: Hurst \& Co., 216-234.

. 1998. 'Pentecostalism, Cultural Memory and the State: Contested Representations of time in Postcolonial Malawi'. In Richard Werbner (ed.), Memory and the Postcolony: African Anthropology and the Critique of Power. London and New York: Zed Books, $155^{-181 .}$

Werbner, Richard. 2011. Holy Hustlers, Schism, and Prophecy: Apostolic Reformation in Botswana. Berkeley: University of California Press.

\section{Notes}

1 See special issue of Journal of Religion in Africa 41.3 (2011) on personhood in African Christianities.

2 In Christian theology the term "pneumatology" refers to the study of the Holy Spirit. Since the spiritual realm has preeminence in local cosmology, Christians in Calabar focus on the power of the Holy Spirit to protect and bless them. It is therefore fitting that the most successful Pentecostal pastors should study the ways of and means for knowing the Holy Spirit.

3 In the Gospel of John, the Greek words Zoe and Psuche are both used to mean 'life'. John's use of Psuche translates as 'soul' and denotes physical life. Zoe is used to mean eternal life and indicates God's spiritual vitality, understood at The Brook Church as life of immeasurable quality. The Bible passage frequently used to illustrate Zoe comes from John 10: 10, 'The thief comes only to steal and destroy; I have come that they may have life, and have it to the full' (New International Version).

4 While Marshall's (2009) analysis of Pentecostalism points to the internalisation of religious action in making religious subjects able to overcome the struggles of the Nigerian postcolony, it is helpful to consider how congregants can actually discern which religious practices aid personal success and also how an individual's practices are shaped by others. For Berliner and Sarro (2007), whose edited volume tries to move away from cognitive anthropological analyses of religious transmission, the learning process arguably comes through religious experience.

5 Houseman (2007) argues that the relationships between both humans and spirits inherent in rituals are more important than the practices. Although Houseman's analysis of rituals for first menses illuminates participants understanding 'exceptional' rituals, the idea of empathy is also central to young women's experiences of more mundane and repetitive Pentecostal practices. 